Research Article

\title{
Cognitive Styles and Gender as Predictors of Students' Achievement in Summary Writing in Selected Secondary Schools in Ibadan, Nigeria
}

\author{
Oladotun Opeoluwa Olagbaju \\ Department of Linguistic Education, College of Education and Social Sciences, Legacy University, Banjul, Gambia \\ Correspondence should be addressed to Oladotun Opeoluwa Olagbaju; dotunolagbaju@yahoo.com
}

Received 14 September 2019; Revised 2 December 2019; Accepted 3 January 2020; Published 22 January 2020

Academic Editor: Paul S. Szalay

Copyright (c) 2020 Oladotun Opeoluwa Olagbaju. This is an open access article distributed under the Creative Commons Attribution License, which permits unrestricted use, distribution, and reproduction in any medium, provided the original work is properly cited.

\begin{abstract}
Performance in the English language especially in public examinations in Nigeria has been very poor with summary writing identified as one of the dreaded aspects of the subject. Research efforts have shown that instructional practices in English studies are not tailored to learners' personality traits such as cognitive style and gender. Cognitive style is an individual's preferred means of receiving, processing, and making use of information. Gender also plays an important role in the teaching-learning process. This study considered the global and analytic dimensions of cognitive style. This study determines to what extent cognitive style and gender can predict students' achievement in summary writing. The research design is descriptive with 350 participants drawn from four senior secondary schools in Ibadan. Data were analyzed using regression analysis, and the results show that cognitive style and gender are predictors of students' achievement in summary writing. Teachers are encouraged to individualise instruction through the knowledge of learner-related variables.
\end{abstract}

\section{Introduction}

The status of the English language in Nigeria has evolved over a long period of time from the language of the colonial masters (preindependence) to the official language and lingua franca (postindependence). Despite the fact that the English language is not indigenous to Nigeria, it has become the language of convenience which has helped to weld together the various ethnolinguistic groups in the country. English language is the first official language, the language of education from the upper primary schools to the higher institutions of learning in Nigeria and one of the core subjects in the Nigerian educational system. Therefore, the different skills of the language are taught as part of the curriculum for English studies. Success in the English language is very important to any student that wishes to gain admission into and succeed in the different levels of education, especially the higher institutions of learning in Nigeria.
English language is one of the core subjects taught in the Nigerian school system. In spite of the importance attached to the teaching and learning of English studies, students' achievement in the subject especially in external examinations has remained poor. Komolafe and Yara [1] posited that students' performance in English, as revealed in various examinations in both the subject and other subjects examined in the English language, is still very low. WAEC Chief Examiners' report [2] identified poor writing skill as one of the factors responsible for the perennial poor performance of students in English. Similarly, Kolawole [3] submitted that any candidate that wishes to do well in the subject must do well in aspects of the English language examination that tests the writing skills such as essay or letter writing, comprehension passage, and summary writing.

In realisation of this fact, scholars such as Olaboopo [4], Fakeye [5], and Komolafe and Yara [1] to mention just a few worked on improving the quality of instruction in composition writing while Fakeye [6] and Adebiyi [7] worked on 
English comprehension. Also, Ojedokun [8], Aragoni [9], and Olagbaju [10] worked on summary writing. Although these studies provided remarkable insights which have impacted classroom practices in the different aspects of the English language, students' performance in the subject, especially in public examinations, has remained generally low. This shows that there are other factors that contribute to students' poor performance in English examinations apart from the choice of instructional strategy.

From the above, it can be inferred that most of the studies aimed at improving students' performance in English have largely focused on investigating the effectiveness of instructional strategies with little or no attention to learner-related factors in the process of teaching and learning. According to Celce-Murcia [11], understanding the way people learn is crucial and is the key to educational improvement. Similarly, Fakeye [12] reported that studentrelated variables can predict achievement in English. The fact remains that people learn in different ways and through diverse means. The knowledge of this fact is required for a rethink of the processes of instructional planning and presentation. Therefore, there is a need for a paradigm shift from instructional strategy-based research to learner-related variables such as learning style, verbal ability, interest, attitude, cognitive styles, and gender towards improving learning outcomes in English language.

Cognitive style is a psychological concept that emphasizes the fact that individuals perceive and process information differently. In the course of learning or acquiring a new knowledge, learners come in contact with information and their cognitive style determines the most consistent way that they perceive, process, or utilise the information that they are exposed to. Learners confront learning tasks with different unique qualities or attributes which can be physical, social, and intellectual, and these qualities play very important roles in their learning. According to Zeeb [13], cognitive style determines how individuals perceive, receive, and process information.

A mismatch in learner's cognitive style and the teacher's teaching style in classroom instruction has dire implications for students' achievement and attitude. Therefore, it is important to pay attention to understanding the way people learn or process information. People learn in different ways; therefore, there are different cognitive style dimensions. Stapa [14] posited that teaching effectiveness is incomplete without the knowledge of certain learners' traits such as cognitive style and learning preferences. Some of the common cognitive style dimensions are field divergent/ convergent, field-dependent/independent, holistic/sequential, and reflective/impulsive [15]. However, the focus of this study is on the global/analytic cognitive style dimension.

Learners with the analytic cognitive style need to break the processing of information into its component parts while global learners will have to view the task as a whole before proceeding to construct meaning. The effects of cognitive style on students' achievement have been investigated in a number of studies, for example, Ezike [16] investigated on students' achievement in chemistry, Okoruwa [17] on integrated science, and Fakeye [6] on English as Second
Language (ESL) students' achievement and attitude to English comprehension. These studies found cognitive style to have contributed significantly to improving learning outcomes in these subject areas. However, Garton et al. [18] found a low positive relationship between students' cognitive style and achievement. Therefore, this study investigated the extent to which cognitive style can predict students' learning outcomes in summary writing.

Similarly, gender has been found in many studies to contribute to students' achievement and attitude. Tatarinceva [19] described gender as social and psychological experiences which determine the differences that emerge and are developed in individuals. The study by Dijkstra [20] on cognitive abilities or intelligence presented the assumption that females are intellectually inferior while Gadwa and Griggs [21] provided scientific evidence that suggests that females and males are equally intellectually capable. With all of these contradictions, the debate on the effects of gender on students' learning outcomes seems to be inconclusive.

The choice of summary writing as an aspect of English studies in this paper is based on its importance in daily life. Knowing how to write a summary is essential if students are to be active listeners, good readers, responsible researchers, and efficient writers [9]. Summary is an unconscious act in language use because it is impossible to give a verbatim report of everything that one has seen, read, experienced, or heard. All these point to the fact that summary skills are important for interactional and transactional use of the English language. Summary skills aid the ability to form or take notes, write examinations, and interact effectively in a community without unnecessary repetitions or redundancies in expression.

In view of the important role that summary skills play in communication, examinations, independent study, and everyday use of the English language, it is disturbing that a good number of students still do not perform well in this aspect. Studies $[22,23]$ have attributed this trend to student and text-related factors such as the inability of students to read or comprehend the passage well, text type or genre, vocabulary, sentence structure, mindless lifting, text readability and organisation, text length, and inability of students to write the answers in their own words and in grammatically correct sentences, among others. Also, Kim [24] argued that effective readers are able to form a mental summary of important information in the passage as they read. It is in view of this that this study examined students' cognitive style and gender as predictors of learning outcomes in summary writing.

\section{Hypotheses}

The following null hypotheses were tested at 0.05 level of significance:

$\mathrm{Ho}_{1}$ : there is no significant relationship between independent variables of cognitive style and gender on students' achievement in summary writing

$\mathrm{Ho}_{2}$ : there is no significant composite contribution of cognitive style and gender on students' achievement in summary writing 
$\mathrm{Ho}_{3}$ : there is no relative contribution of cognitive style and gender on students' achievement in summary writing

\section{Theoretical Framework}

3.1. Personality Trait Theory. Traits refer to the general ways of describing an individual. Traits are consistent or stable characteristic that causes a person to respond to any situations in certain ways regardless of the situations. Descriptive terms such as careful, aggressive, quiet, and outgoing are all traits. Gordon Allport [25] was one of the psychologists to come up with a personality trait theory. He considers traits as building blocks of personality. The theorists categorise personality traits into three: cardinal traits which play such an important role in a person's life that they often become synonymous with such traits as greed and kindness; the second category is central traits which lead to the foundation of an individual's personality; and secondary traits refer to the general behaviour patterns that only appear under certain circumstances. For example, an individual can be nervous to speak in public.

In relation to this paper, Hardijzer [26] posited that cognitive style is a term usually used to refer to the link between cognitive assessment, ability, and personality. It deals with the integrative styles of thinking, acting, and expressing personality. It relates to the consistency in how an individual receives processes and makes use of any given information. Prinsloo and Voss [27] cited in Hardijzer [26] averred that cognitive styles partly cover an individuals' personality to some extent. This further reinforces the concept of individualised instruction based on personality traits and individual differences in learning. Therefore, this study considers the relationship between global and analytic cognitive style dimensions and students' achievement in summary writing.

\section{Review of Related Literature}

4.1. Instructional Practices in Summary Writing. Summary writing, like other aspects that test students' comprehension and knowledge of the writing skill in English language, has its own problematic area. Some of these problems are human-related while others are subject-based; these problems include poor knowledge of summary skills by language teachers, poor reading skills, vocabulary, grammar and spelling errors, direct lifting from the original passage, writing out answers as points, and the inability to write the summary answers in writer's own words. The structure of a summary passage is such that every paragraph illuminates the thesis statement by providing supporting details, examples, illustrations, or explanations. Topic sentences are general statements which contain the main point discussed in the paragraph and they are usually written alongside other supporting details.

Sasson [28] suggested that students should be encouraged to read their summary passage aloud during the course of instruction while teachers guide and task them to pay attention to the vocabularies, supporting sentences, and cues that could point at the topic sentences in the text while listening. Ojedokun [8] stressed the importance of preteaching key vocabularies, grammatical structures, phrases, idioms, and/or cultural information in the passage in order to aid the comprehension of the text. It is therefore necessary that language teachers pay attention to these aspects of the passage in the teaching of summary writing to facilitate comprehension and retention of the gist.

Several tasks are involved in the teaching and learning of summary writing as an aspect of the English language. According to Aniga and Ellah [29] and Olagbaju [10], these tasks include effective reading of the passage, identification of the topic sentence or thesis statement in the paragraphs, differentiation between the topic sentence and other supporting sentences which are usually in the form of illustrations and examples, identification and replacement of vocabularies in the topic sentences, and rewriting the summary answer in the students' own words. Due to the complexities involved in the teaching of summary writing, teachers need to ensure that this aspect of English language is properly taught in schools. However, Roberts and Dyer [23] submitted that as important as success in summary writing is, it has become a dreadful aspect of the English language examinations to many candidates because they are not properly prepared or taught by teachers.

Also, some language teachers have poor attitude and knowledge of summary writing skills and the implication is that many of their students do not know how to summarise so they usually perform poorly in summary writing. Performance of students in summary writing has been linked to the effectiveness or otherwise of instructional strategies by teachers and other student-related variables such as attitude, verbal ability, gender, and cognitive style. On attitude, Yara [30] noted that it is concerned with an individual's way of thinking, acting, and behaving. Attitude represents an individual's degree of like or dislike for something. Attitudes are formed over time and they have very serious implications for everyone concerned with the process of teaching and learning: the learner, the teacher, classmates, the entire school system, and others. They are either positive or negative and they can facilitate or hinder the teaching and learning process in the classroom.

4.2. Cognitive Style and Learning. Students come into the classroom and learning situations with their individual traits as well as diverse unique attributes which can be physical, social, and intellectual. These unique qualities play very important roles in their learning. People differ in their choice of perception, processing, and making use of information during teaching/learning encounters and this has been referred to as cognitive style $[6,16,17,31]$. An individual's cognitive style is his or her consistent way of responding to, interpreting, and using stimuli in the context of learning. Therefore, cognitive style is not really concerned with what learners want to learn; rather, it is the unconscious cognitive processes involved in the way they learn.

In addition, cognitive style dimensions are personality traits consistently displayed or adopted by individuals over a 
period of time for processing information. Many of these traits have been identified by scholars $[32,33]$ as empirically stable forms of information-seeking behaviour. Cognitive style is both innate and habitual approach to processing information especially when one is exposed to tasks such as problem-solving, thinking, perceiving, and remembering. Reid [34] classified cognitive style into different dimensions which are field-independent/field-dependent (field-independent learners learn more effectively step by step, beginning with analyzing facts and proceeding to ideas, and field-dependent learners, in contrast, prefer to learn in context and holistically); analytic/global (analytic learners learn individually and prefer setting goals, and global/holistic learners, on the other hand, learn more effectively through concrete experience and by interaction with other people); and reflective/impulsive (reflective learners learn more effectively when they have time to consider options before responding while impulsive learners are able to respond immediately and take risks).

This study views cognitive style from the global/analytical dimension. Pask [35] cited in Ford et al. [15] reported that global learners tend to adopt a global approach to learning, that is, examining interrelationships between several topics early in the learning process and concentrating first on building a broad conceptual overview into which detail could subsequently be fitted. The analytical learners on the other hand make use of a predominantly local learning approach to examine one thing at a time and concentrate on separate topics (parts) and the logical sequences linking them. Then the overall picture would emerge relatively late in the learning process.

Similarly, Fleming [36] averred that global learners like to start with a big idea or concept, then go on to study and understand the parts. Learners in this category may likely seek to read and read but become frustrated, and then, they suddenly arrive at or identify the answers they were looking for. On the contrary, analytic learners work through the different parts and bits (before getting the big picture) only bringing them together late in the learning process when absolutely necessary to achieve understanding, while global learners see the big picture first and constantly move between theory and real world right from the start; people with the analytical cognitive style learn things step by step, or sequentially.

Crowl et al. [37] described analytic learners as people who tend to perform better when working in structured situations and they are also efficient when working in formal settings, that is, under minimal guidance or supervision. Global learners require lesser structure and fewer instructions to perform well in school tasks because they tend to glaze over material to pursue the big idea and this can be ineffective, especially during test or examination situations because those small details often show up in tests. Okoruwa [17] averred that a learner with a particular style is more likely to benefit more from a particular teaching strategy than the others.

Wintergerst et al. [38] found that cognitive style has significant effects on students' achievement in English as a foreign language. Also, Reid [34] and Stapa [14] in separate studies investigated the effects of students' cognitive style on ESL/EFL students' achievement in the target language and found that students with the global cognitive style performed better than the analytic group. Garton et al. [18] reported a low positive relationship between cognitive style and students' achievement in the course taught by the first and fourth instructors. A mismatch between teaching style and students' cognitive style will likely impede the learning process.

In relation to the teaching and learning of summary writing, students with the analytic cognitive style dominance break the summary passage into composite parts and take each of the parts step by step while global learners maintain a holistic approach in reading or processing information to facilitate text comprehension.

4.3. Gender and Learning Outcomes. Several studies have investigated the effects of gender on students' achievement in different subject areas and their findings have remained inconclusive. For example, Roberts [39] lamented that gender differences in achievement are widely reported across grades, countries, and languages. Girls' superiority in reading and writing has been widely observed to maintain relatively static pattern for at least the last forty years. At the same time, the historical gender gap in mathematics and science, in which boys previously outperformed girls, continues to decline with no meaningful differences being found in mathematics achievement in several countries. Similarly, National Centre for Education Statistics [40] cited in Zembar and Blume [41] reported that females are better in the aspects of spelling, literacy, writing, and general knowledge.

Further still, Connell and Gunzelmann [42] described brain-based gender differences as a data-based and empirical explanation for these differences. Other research studies suggest that boys and girls effectively use different parts of their brain, with each group exhibiting stronger left-hemisphere strength in different capacities. The left-hemisphere strength of females gives them an advantage in language skills such as speaking, listening, reading, and writing while the left-hemisphere strength of males allows them to outperform females in linguistic/cognitive processes that involve categorization and recall of information [43-45].

Also, Tatarinceva [19] suggested that teachers should know their students' needs, goals, cognitive style, and the implications of their gender differences as this is capable of improving students' achievement and attitude to learning. The findings of a study in 2004 by the National Centre for Education Statistics (NCES) provided an analysis of gender differences in reading achievement. The study was aimed at investigating the administration of the National Assessment of Educational Progress between 1992 and 2003. This result revealed that females consistently performed better than their male counterparts in reading achievement. Also, the females outperformed males in writing achievement in 1998 and 2002.

Cavanaugh [46] argued that males and females learn differently from each other. For instance, males tend to be 
more kinaesthetic, tactual, and visual, and they need more mobility in a more informal environment than females. Males are largely known to be self-assertive, recalcitrant, and peer-motivated than females who tend to comport themselves well in a classroom and learn better through listening. Also, Gates [47] opined that female students have advantages over their male counterparts in three measures of reading which are speed reading, vocabulary, and comprehension. However, Dijkstra [20] reported that females are intellectually inferior. Also, Zembar and Blume [41] argued that the influence of gender on students' achievement can be traced to gender differences in the cognitive abilities of middle-school students. Therefore, the relationship between gender and students' learning outcome is investigated in this study to determine the extent to which gender can predict achievement in summary writing.

\section{Methodology}

5.1. Research Design. The study adopted a descriptive survey design of a correlational type because the researcher had no direct control of the independent variables as their manifestations have already existed. Correlational research is a nonexperimental approach used to investigate the relationships between/across variables. The manifestations of the independent variables in the study were examined to ascertain their significant predictive relationship with the dependent variables.

5.2. Population of the Study. The target population of the study comprised all the senior secondary school two (SSII) English language students in the five local government areas in Ibadan metropolis, Nigeria.

5.3. Sampling Techniques and Sample. Participants for this study were randomly selected from four senior secondary schools in Ibadan South-West and Ibadan North Local Government Areas of Oyo State. 350 senior secondary school students in class II were randomly selected from the two local governments. Two senior secondary schools were purposively selected from each of the local government areas based on the following criteria:

(i) The school must be a coeducational institution

(ii) The school must have been presenting candidates for public examinations for at least five years

Therefore, Baptist Secondary School, Oke-Ado; IMG Grammar School II, Sharp Corner; Anglican (Commercial) Secondary School, Orita-Mefa; and Abadina College, Agbowo, were used in the study.

5.4. Variables in the Study. The study was guided by two independent variables and one dependent variable. The independent variables were used to predict senior secondary students' achievement in summary writing. The variables are classified accordingly:

Independent variables: (i) Students' cognitive style at two levels:

(a) Global

(b) Analytic

(ii) Students' gender at two levels:

(a) Male

(b) Female

Dependent variable:

(i) Students' achievement in summary writing

5.5. Instruments. Two instruments were used in this study. These include:

(1) Cognitive style inventory (CSI)

(2) Summary writing achievement test (SWAT)

5.5.1. Cognitive Style Inventory (CSI). The instrument was adapted from Lorna Martin [31] to assess the global and analytic cognitive style dimensions. The inventory contained 36 items numbered using alphabet range of $\mathrm{A}$ to $\mathrm{JJ}$ with a five-point scale of strongly agree (SA), agree (A), undecided $(\mathrm{U})$, disagree (D), and strongly disagree (SD) scored 1, 2, 3, 4, and 5 , respectively, before it was adapted into a 30-item fourpoint scale of strongly agree (SA), agree (A), disagree (D), and strongly disagree (SD) based on $4,3,2$, and 1, respectively. The numbering pattern was changed from alphabets to a numeral range of 1 to 30 . All the items in the inventory were positively stated; items that fall into the odd number group addressed the global cognitive style dimension while the items in the even number group covered the analytic group. Therefore, there were a total of 15 items per group in the cognitive style inventory (CSI). Section A covered the demographic information of each of the respondents such as name, class, sex, and age, while section B comprised a 30-item questionnaire. To determine the reliability and internal consistency, the instrument administered to a group of students outside the sample and analysed using Cronbach alpha formula. The standardised alpha value of 0.74 was obtained.

5.5.2. Summary Writing Achievement Test (SWAT). The instrument was a passage adopted from the students' recommended textbook. It was a summary passage titled, "The features of poverty". SWAT was used to measure students' achievement in summary writing. Questions set on the passage were made parallel to those obtained in WASSCE examinations. The reliability of the instrument was ascertained by using the test-retest method at two-week interval, and a reliability coefficient of 0.81 was obtained. SWAT was scored using the criteria suggested in the WASSCE marking guides for May/June 2012. That is,

(1) Five (5) marks were awarded for every correct answer

(2) Zero was awarded for a mindless lifting 
(3) Half $(1 / 2)$ mark was deducted for every spelling mistake

(4) Half of the marks allotted for a correct answer awarded for answers that were not written as sentences

5.6. Procedure for Data Collection. The researcher and two research assistants went to sample schools to interact with the English language teachers in the schools selected for the study. Fieldwork commenced the following week and the exercise lasted for a period of three weeks. CSI and SWAT were administered simultaneously in each of the schools to prevent unnecessary interference.

5.7. Methods of Data Analysis. The data collected were subjected to Pearson product-moment correlation (PPMC), multiple regression analysis (MRA), and other descriptive statistics tools such as mean, frequency count, standard deviation, and simple percentage. This was meant to investigate the extent of relationship and contribution of cognitive styles and gender on students' achievement in summary writing in Ibadan. All hypotheses were tested at 0.05 alpha level.

\section{Results and Discussion}

Hypothesis 1. There is no significant relationship between the independent variables of students' cognitive style and gender on students' achievement in summary writing.

Table 1 shows that students' cognitive style has a positive significant relationship on students' achievement in summary writing $(r=0.558 ; P<0.05)$. This implies that students' cognitive style is related to students' achievement in summary writing. Also, students' gender correlates significantly with students' achievement in summary writing $(r=0.138$; $P<0.05)$. This means that the relationship between students' gender and achievement in summary writing is significant. Hence, the null hypothesis which states that there is no significant relationship between the independent variables of cognitive style and gender on students' achievement in summary writing is rejected.

Hypothesis 2. There is no significant composite contribution of independent variables of cognitive style and gender on students' achievement in summary writing.

Table 2 shows that the composite contribution of independent variables of cognitive style and gender on students' achievement in summary writing $\left(F_{(2,349)}=15.04\right.$; $P<0.05)$. The table also shows a multiple regression squared index $\left(R^{2}\right)$ of 0.601 . This implies that $60.7 \%$ of the total variation in the achievement of students in summary writing is attributable to the composite contribution of independent variables of students' cognitive style and gender. Therefore, the null hypothesis that states that there is no significant composite contribution of independent variables of cognitive style and gender on students' achievement in summary writing is rejected.
Hypothesis 3. There is no relative contribution of independent variables of cognitive style and gender on students' achievement in summary writing.

Table 3 shows the relative contribution of the two independent variables on the dependent variables. The relative contribution of students' gender on students' achievement in summary writing was significant $(\beta=0.258 ; t=6.58$; $P<0.05)$ and that of cognitive style on students' achievement in summary writing was also significant $(\beta=0.324$; $t=7.13 ; \quad P<0.05)$. Cognitive style $(\beta=0.324 ; \quad t=7.13$; $P<0.05)$ contributed more to students' achievement in summary writing than gender $(\beta=0.258 ; t=6.58 ; P<0.05)$. Hence, the null hypothesis that states that there is no relative contribution of independent variables of cognitive style and gender on students' achievement in summary writing is rejected. Table 4 shows the different levels of the relative contribution of the independent variables on students' achievement in summary writing.

Table 4 shows the order of predictive capability of the relative and composite contributions to students' achievement in summary writing in the study. The implication of this is that the two independent variables are good predictors of students' achievement in summary writing at $P<0.05$ alpha level of significance.

6.1. Discussion of the Result. The findings of this study revealed that students' cognitive style and gender can predict their achievement in summary writing. Students with analytic cognitive style had a higher mean achievement score than those with the global cognitive style. The result agrees with the findings of Bassey et al. [48] that students with analytic cognitive style had higher significant mean achievement score than those with relational and inferential cognitive style. However, the result disagrees with the findings of Awofala et al. [49] that students with nonanalytic cognitive style had higher mean achievement score than students with analytic cognitive style. On similar studies in English language $[6,14]$ reported that global learners performed significantly better than their analytic counterparts in ESL/EFL classroom.

With regard to gender, this study is in line with the findings of Gates [47] and Tatarinceva [19] that gender differences have serious implications for students' achievement in language learning. However, this study does not support the findings of Gadwa and Griggs [21] and Olagbaju [10] that gender differences have no effect on students' achievement in learning. This study has shown that achievement in summary writing as an aspect of English language can be predicted by students' gender. The findings of this study on the composite contribution of the two independent variables reveal that there is a significant contribution of the independent variables on achievement in summary writing. The composite effect of the independent variables on students' achievement in summary writing is significant at different levels. However, the combined positive significant relationship and contribution of the cognitive style and gender on students' achievement in 
TABLE 1: Correlation matrix of cognitive style and gender on students' achievement in summary writing.

\begin{tabular}{lccc}
\hline & Students' achievement in summary writing & Students' gender & Students' cognitive style \\
\hline Students' achievement in summary writing & 1 & & \\
Students' gender & $0.138^{*}$ & 1 & 1 \\
Students' cognitive style & $0.558^{*}$ & $0.341^{*}$ & 75.988 \\
Mean & 15.135 & 64.907 & 8.799 \\
Std. deviation & 11.949 & 8.963 & \\
\hline
\end{tabular}

*Significant at $P<0.05$ alpha level.

TABLE 2: Multiple regression analysis showing the composite contribution of independent variables on students' achievement in summary writing $\left(R=0.812, R^{2}=0.609\right.$, and adjusted $\left.R^{2}=0.607\right)$.

\begin{tabular}{lcccr}
\hline Model & Sum of squares & Df & Mean square & $F$ \\
Regression & 8308.41 & 2 & 1445.3 & Sig. \\
Residual & 120683.79 & 347 & 96.1 & $15.04^{*}$ \\
Total & 128992.20 & 349 & & 0.000 \\
\hline
\end{tabular}

${ }^{*}$ Significant at $P<0.05$ alpha level.

TABLE 3: Relative contribution of independent variables on students' achievement in summary writing.

\begin{tabular}{|c|c|c|c|c|c|c|}
\hline \multirow{2}{*}{ Predictor variables } & \multicolumn{2}{|c|}{ Unstandardized coefficient } & \multirow{2}{*}{$\begin{array}{c}\text { Standardized coefficient } \\
\text { Beta }(\beta)\end{array}$} & \multirow{2}{*}{ Rank } & \multirow{2}{*}{$t$} & \multirow{2}{*}{ Sig. } \\
\hline & Beta $(\beta)$ & Std. error & & & & \\
\hline Constant & 0.502 & 5.554 & & & 8.43 & 0.000 \\
\hline Students' gender & 0.371 & 0.035 & 0.258 & 2nd & $6.58^{*}$ & 0.000 \\
\hline Students' cognitive style & 0.465 & 0.035 & 0.324 & $1 \mathrm{st}$ & $7.13^{*}$ & 0.000 \\
\hline
\end{tabular}

*Significant at $P<0.05$ alpha level.

TABLE 4: Relative contribution of independent variables on students' achievement in summary writing.

\begin{tabular}{lcc}
\hline$S / N$ & $\begin{array}{c}\text { Predictor } \\
\text { variables }\end{array}$ & $\begin{array}{c}\text { Order of predictive } \\
\text { capacity (ranking) }\end{array}$ \\
\hline 1 & Students' gender & $2^{\text {nd }}$ \\
2 & Students' cognitive style & $1^{\text {st }}$ \\
\hline
\end{tabular}

summary writing could be because the two variables are connected to the learners' personality traits.

\section{Summary of Findings}

There is a positive significant relationship between the independent variables (cognitive style and gender) and students' achievement in summary writing. Students' cognitive style had a higher score than gender.

(1) There is a significant composite contribution of independent variables on students' achievement in summary writing. By multiple regression analysis, above average in the achievement of students' in summary writing is attributable to the joint effect of independent variables in the study. However, the contribution of each predictor variable to students' achievement in summary writing was at different levels.

(2) There was a positive significant relative contribution of the independent variables on students' achievement in summary writing. Cognitive style had higher scores than gender in facilitating students' achievement in summary writing.

\section{Conclusion}

The study examined the extent to which cognitive style and gender would predict students' achievement in summary writing. The result of this study revealed that students' personality traits such as cognitive style and gender are effective at improving students' achievement in summary writing. The independent variables in the study have significant composite and relative contributions and relationship to students' achievement in summary writing. Based on the findings of this study, it was concluded that English language teachers should individualised instructions in summary writing in order to cater for the different learning preferences and variations in personality in the classroom. Therefore, teachers should make conscious efforts to ensure that no learner is left behind by creating a classroom environment where all the learners can express themselves and learn according to their cognitive style orientations.

\section{Recommendations}

(1) Instruction in summary writing should be tailored to meet the need of individual students and their cognitive style orientations

(2) Preservice and in-service English language teachers should be trained to create a classroom atmosphere that incorporates learner-centred variables such as cognitive styles and gender into the teachinglearning procedure 
(3) There is a need for further research to investigate the effects of cognitive styles and gender on other learning outcomes such as students' interest, attitude, verbal ability, or any other dependent variable

(4) The study should be replicated to investigate the effects of the independent variables on learning outcomes in other aspects of English language such as reading comprehension, composition writing, or other subject areas

(5) There is a need for a paradigm shift in teacher-education research from emphasis on instructional strategies to learner-related variables

(6) Learner-centred instruction through participatory and team-focused approach should be encouraged in the teaching of summary writing

\section{Data Availability}

The descriptive data used to support the findings of this study are included within the article.

\section{Conflicts of Interest}

The authors declare that they have no conflicts of interest.

\section{References}

[1] A. T. Komolafe and P. O. Yara, "Sentence combining strategy and primary school pupils achievement in written English in Ibadan, Nigeria," European Journal of Scientific Research, vol. 40, no. 4, pp. 531-539, 2010, ISSN 1450-216X.

[2] West African Examinations Council, WAEC Chief Examiners' Report for the West African Senior School Certificate Examination (WASSCE), WAEC Press, Lagos, Nigeria, 2018.

[3] C. O. O. Kolawole, Linguistic inputs and three methods of presentation as determinants of students' achievement in senior secondary school essay writing in Ibadan, An Unpublished Ph.D. Thesis, University of Ibadan, 1997.

[4] A. O. Olaboopo, Effects of error-treatment, model-based and skill-based instructional strategies on senior secondary school students' achievement, motivation and attitude to composition writing, An Unpublished Ph.D. thesis, University of Ibadan, Ibadan, 1999.

[5] D. O. Fakeye, Relative effects of instruction in componential and rhetorical strategies on senior secondary school students' achievement in essay writing in Ibadan, An Unpublished Ph.D. thesis, University of Ibadan, 2001.

[6] D. O. Fakeye, "ESL students' cognitive and English comprehension achievement in South Western Nigeria," Nigerian Journal of Counselling and Applied Psychology, vol. 4, no. 1, pp. 23-30, 2008.

[7] E. F. Adebiyi, "Effects of explicit and generative instructional strategies on students' achievement in reading comprehension in ikere local government area of Ekiti State," An Unpublished M.Ed Project Submitted to the Department of Teacher Education, University of Ibadan, Ibadan, Nigeria, 2012.

[8] R. I. Ojedokun, Literature circle, semantic mapping and senior secondary school students' learning outcomes in summary writing in English language, An Unpublished Ph.D. thesis, University of Ibadan, Ibadan, Nigeria, 2010.
[9] L. Aragoni, "Teach how to write a summary reading, writing, studying require it," 2011, http://www.you-can-teach-writing. com.

[10] O. O. Olagbaju, Effects of explicit and generative instructional strategies on senior secondary school students' learning outcomes in summary writing in Ibadan metropolis, Nigeria, An Unpublished Ph.D. thesis, University of Ibadan, Ibadan, Nigeria, 2015.

[11] M. Celce-Murcia, Teaching English as a Second or Foreign Language, Dewey Publishing Services, New York, USA, 3rd edition, 2001.

[12] D. O. Fakeye, "Students' personal variables as correlates of academic achievement in English as a second language in Nigeria," Journal of Social Sciences, vol. 22, no. 3, pp. 205-211, 2010.

[13] M. S. Zeeb, "Improving students' success through matching learning and teaching styles," An Unpublished Master of Arts in Education (M. A (Ed)) Project, University of Phoenix, Tempe, Arizona, 2004.

[14] S. H. Stapa, "ESL students' learning preferences: are the teachers aware?” 2003, http://www.Esp-world.Info/rticles/ stapa.htm.

[15] N. J. Ford, A. E. Wilson, D. E. Foster, and A. Spink, "Information seeking and mediated searching: cognitive style in information seeking analysis," 2002, http://informationr.net/ tdw/publ/unis/app7.4.html.

[16] B. Ezike, Effects of cognitive style and students' achievement in chemistry, An Unpublished Ph.D. thesis, University of Ibadan, Nigeria, 2007.

[17] E. Okoruwa, Effects of cognitive style and primary school pupils' achievement in integrated science, An Unpublished Ph.D. thesis, University of Ibadan, Nigeria, 2007.

[18] B. L. Garton, J. N. Spain, W. R. Lamberson, and D. E. Spiers, "Cognitive style, teaching performance, and students' achievement: a relational Study," 2010, http://www.jae-online. org/attachements/article/1472/40-30-11.pdf.

[19] A. Tatarinceva, "Influence of the gender factor on a student's cognitive style and achievements in language learning," Mūsdienu Izglitīibas Problēmas, 2009, http://www.tsi.lv/ Research/Conference/MIP_2009/12.pdfa.

[20] B. Dijkstra, Idols of Perversity, Oxford University Press, New York, USA, 2006.

[21] K. Gadwa and S. Griggs, "The dropouts: implications for counsellors," The Counsellor, vol. 33, no. 1, pp. 9-17, 1995.

[22] D. O. Fakeye and Y. Ogunsiji, "English language proficiency as a predictor of academic achievement among EFL students in Nigeria," European Journal of Scientific Research, vol. 37, no. 3, pp. 490-495, 2009.

[23] T. G. Roberts and J. E. Dyer, "The influence of learning styles on student attitudes and achievement when an illustrated web lecture is used in an online learning enviornment," Journal of Agricultural Education, vol. 46, no. 2, pp. 1-11, 2005.

[24] S.-A. Kim, "Characteristics of EFL readers' summary writing: a study with Korean university students," Foreign Language Annals, vol. 34, no. 6, pp. 569-581, 2001.

[25] G. W. Allport and H. S. Odbert, "Trait-names: a psycho-lexical study," Psychological Monographs, vol. 47, no. 1, pp. i-171, 1936.

[26] C. H. Hardijzer, "The relationship between cognitive styles and personality types," An Unpublished Masters Project, University of South-Africa, Pretoria, South Africa, , An Unpublished Masters Project, University of South-Africa, Pretoria, South Africa, 2000.

[27] S. M. Prinsloo and P. Voss, Cognitive Process Profile-Training Manual, Cognadev, Johannesburg, South Africa, 1996. 
[28] D. Sasson, "Guidelines on how to write a clear summary: how critical reading skills helps with summary skills," 2009, http:// www.suite101.com/content/guidelines-on-how-to-write-a-clearsummary-a90971\#ixzz1F6RNO6Dy.

[29] U. S. Aniga and S. M. Ellah, English Language for Daily Communication, Panse Publishers Limited, Ibadan, Nigeria, 2010.

[30] P. O. Yara, 'Students' attitude towards Mathematics and academic achievement in some selected secondary schools in Southwestern Nigeria," European Journal of Scientific Research, vol. 36, no. 3, 2009.

[31] L. P. Martin, "The Cognitive-style inventory," The Pfeiffer Library, Jossey-Bass/Pfeiffer, vol. 8, no. 2, pp. 113-127, 1998.

[32] N. Ford, "Cognitive style and strategies of postgraduate students," British Journal of Educational Technology, vol. 16, no. 4, pp. 65-77, 1995.

[33] S. Cassidy, "Learning styles: an overview of theories, models, and measures," Journal of Educational Psychology, vol. 24, no. 4, pp. 1-27, 2004.

[34] J. Reid, Cognitive Style in the ESL/EFL Classroom, Heinle and Heinle Publishers, Boston, MA, USA, 1995.

[35] G. Pask and B. C. E. Scott, "Learning strategies, teaching strategies, and conceptual or cognitive style," in Learning Strategies and Cognitive Style, R. R. Schmeck, Ed., pp. 83-99, Plenum Press, New York, USA, 1988.

[36] G Fleming, "Holistic and analytic cognitive style," 2005, http:// homeworktips.about.com/od/homeworkhelp/a/global.htm.

[37] T. K. Crowl, S. Kaminsky, and D. M. Podell, Educational Psychology: Windows on Teaching, McGraw-Hill, New York, NY, USA, 1997.

[38] A. C. Wintergerst, A. DeCapua, and M. Ann Verna, "Conceptualizing learning style modalities for ESL/EFL students," System, vol. 31, no. 1, pp. 85-106, 2003.

[39] H. Roberts, "The disadvantages of a traditional classroom," 2009, http://www.helium.com/items/1319506-the-disadvantages-of-atraditional-classroom.

[40] National Centre for Education Statistics, "Average scale scores and achievement- level results in reading by grade," 2006, http:// www.nces.ed.gov/nationsreportcard/nrc/reading_mathematics_ 2005/s0010.asp.

[41] M. J. Zembar and L. B. Blume, Middle Childhood Development: A Contextual Approach, Merrill/Pearson, Upper Saddle River, NJ, USA, 2009.

[42] D. Connell and B. Gunzelmann, "The next gender gap: why are so many boys floundering while so many girls are soaring?" Instructor, Gage, Cengage Learning, Alabama: Project Innovation, Alabama, USA, 2004.

[43] N. D. Cook, "How the two hemisphere collaborate in the processing of language: bihemispheric language. supported by the research for the future program, administered by the Japan society for the promotion of science (project no. JSPSRFTF9901401)," 2002, http://www.thebritishacademy.ac.uk.

[44] O. O. Olagbaju, "The interplay between gender and learning styles: implications for second language teaching," Global Journal of Human-Social Science: G (Linguistics \& Education), vol. 14, no. 2, pp. 15-20, 2014.

[45] P. Wright, E. A. Stamatakis, and L. K. Tyler, "Differentiating he,ispheric contributions to syntax and semantics in patients with left hemispheric lesions," Journal of Neuroscience, vol. 32, no. 24, pp. 8149-8157, 2012.

[46] D. Cavanaugh, Hemispheric Preference, Cambridge University Press, New York, USA, 2002.

[47] A. Gates, "Sex differences in reading ability," Psychological Bulletin, vol. 107, no. 2, pp. 139-155, 2001.
[48] S. W. Bassey, G. Umoren, and L. A. Udida, "Cognitive style, secondary school students' attitude and academic performance in chemistry in Akwa Ibom state, Nigeria," 2007, http://www. hbcse.tifr.res.in/episteme/episteme-2/e-proceedings/bassey.

[49] A. O. A. Awofala, T. A. Balogun, and M. A. Olagunju, "Effects of three modes of personalisation on students' achievement in mathematics word problems in Nigeria," 2011, http://www. cimt.plymouth.ac.uk/journal/awofala.pdf. 


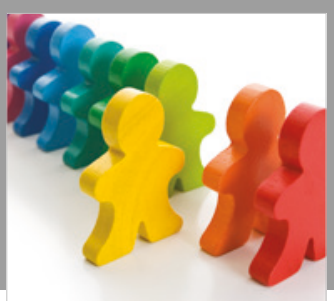

Autism

Research and Treatment
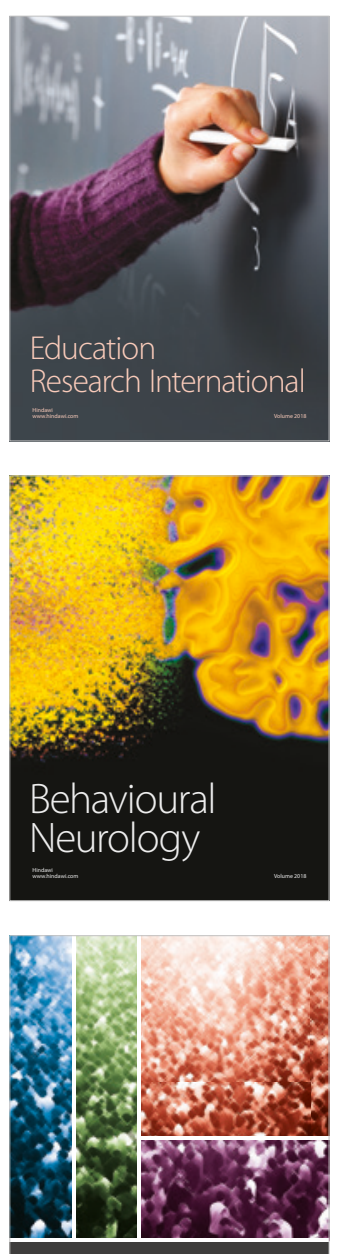

International Journal of

Population Research

$\underline{-m}$

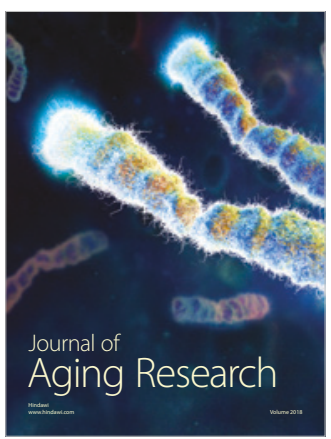

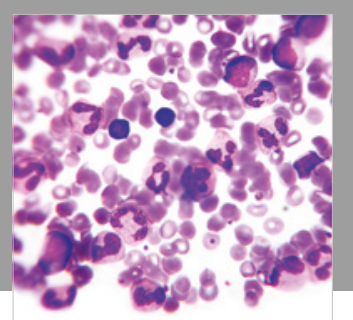

Pathology

Research International$$
=
$$

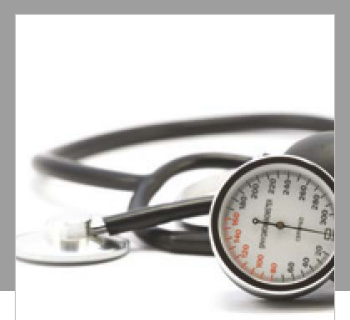

Nursing

Research and Practice

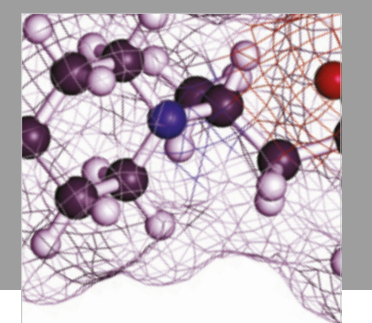

Pain

Research and Management

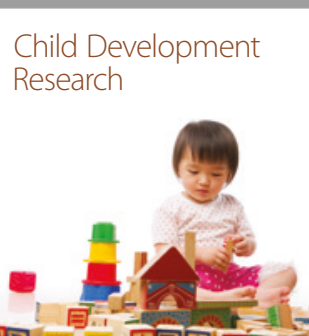

बाD

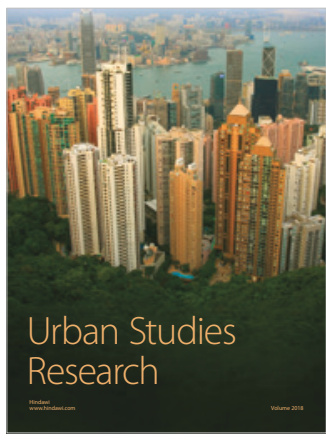

\section{Hindawi}

Submit your manuscripts at

www.hindawi.com
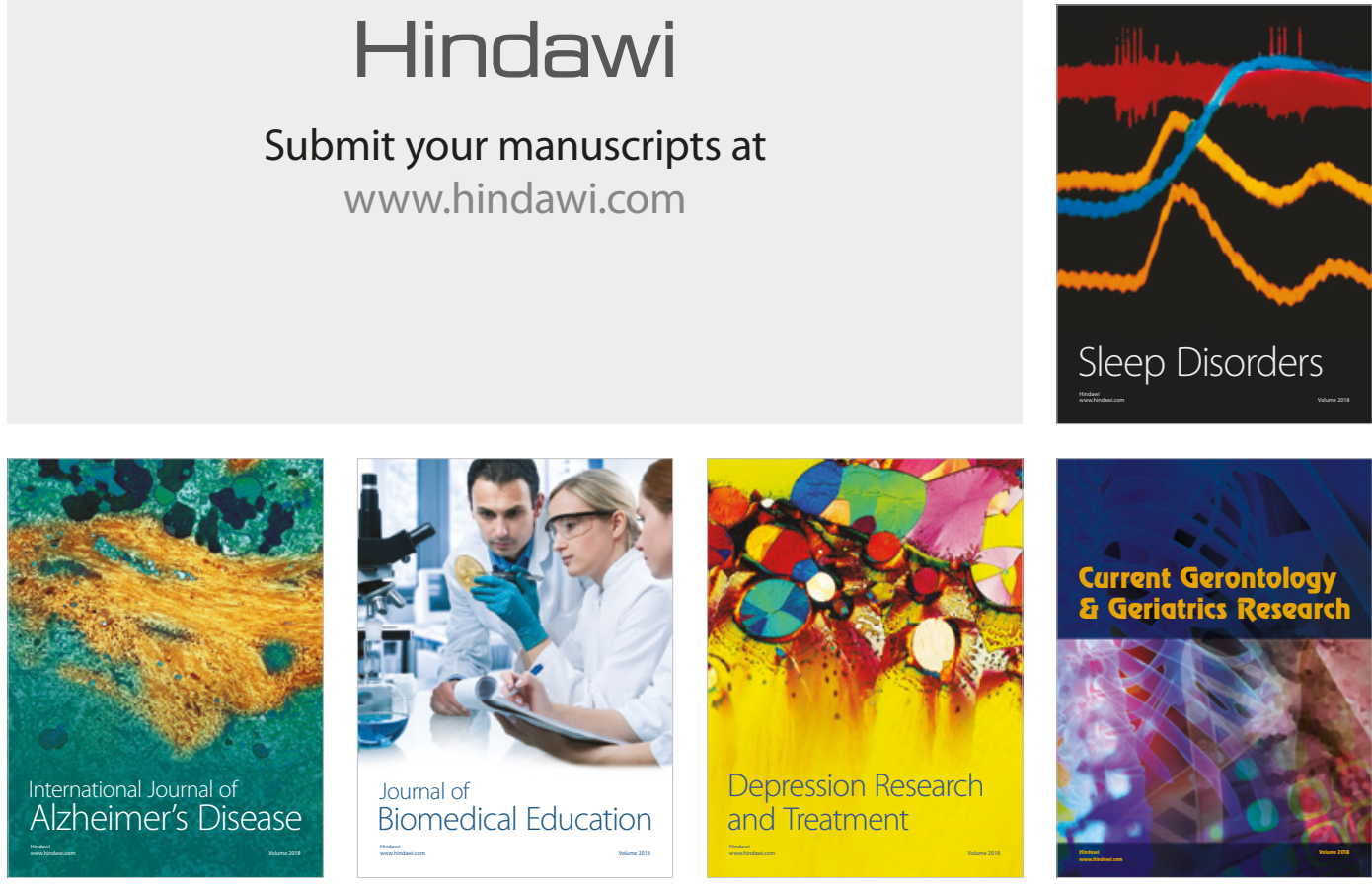

Journal of

Biomedical Education

$=$

smman

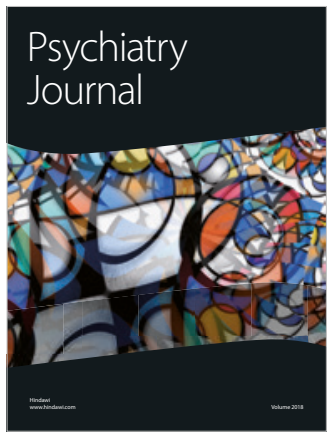

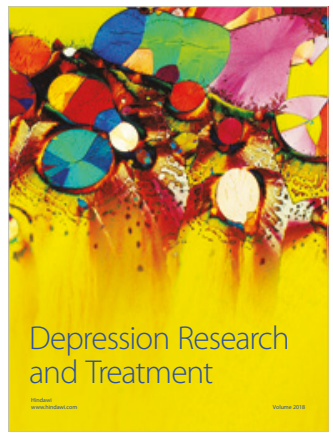
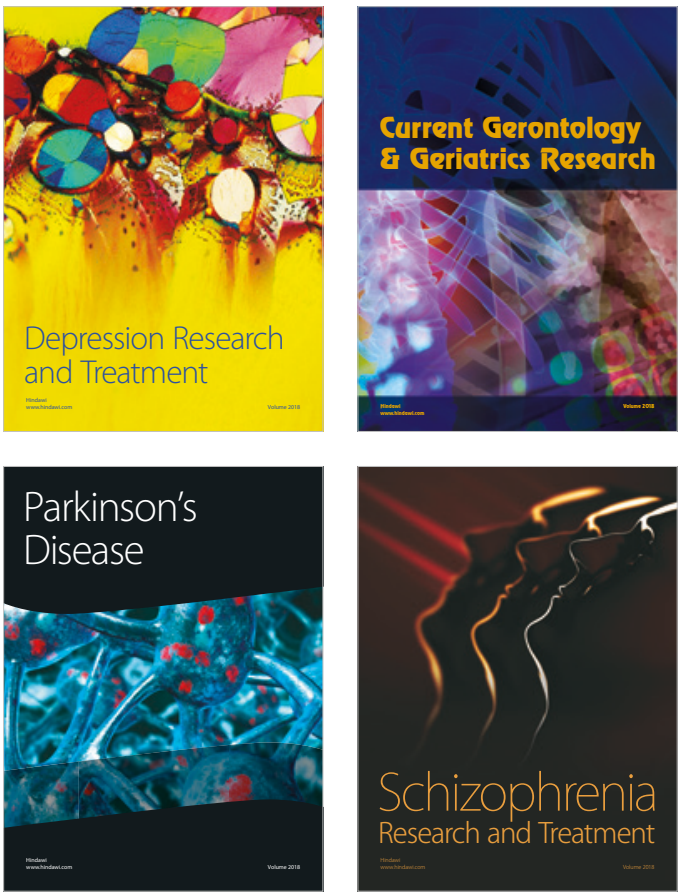